International Journal of Instruction e-ISSN: 1308-1470 • www.e-iji.net

Article submission code: 20200929062000

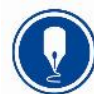

October $2021 \bullet$ Vol.14, No.4

p-ISSN: 1694-609X

pp. 301-320

Received: 29/09/2020

Revision: 11/03/2021
Accepted: 04/04/2021

OnlineFirst: 17/07/2021

\title{
Perceptions of Collaborative Video Projects in the Language Classroom: A Qualitative Case Study ${ }^{1}$
}

Christina Dahee Jung

Asst. Prof., Woosong University, Korea, christinajung@woosong.org

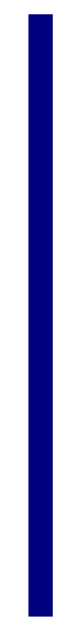

The motivation of language learners is a crucial aspect of effective teaching in the language classroom. Allowing students to interactively experience technologyenhanced learning activities whereby they design, organize, and create collaborative projects such as video-recorded role plays, dialogues, and short films is one motivational approach. The objective of this qualitative case study is to explore the perceptions of post-secondary English-as-a-Foreign-Language (EFL) students on how their collaborative experiences of creating video projects influence their motivation to learn English. This qualitative case study utilizes semi-structured interviews, researcher's field notes, and student artefacts to explore the perceptions and experiences of eight students. Findings reveal that the perceptions of the participants are generally positive with regards to video project collaboration. Furthermore, results also show that self-efficacy and task value are important sociocognitive constructs that impact the language learners' motivational orientation. The results of this study provide new understandings of how technology-enhanced approaches to learning enhance learner motivation in postsecondary EFL learners.

Keywords: motivation, video project, sociocognitive constructs, self-efficacy, task value

\section{INTRODUCTION}

Motivation plays a significant role in language learning. The language learner's motivation creates the impetus to acquire a language (Cheng \& Dörnyei, 2007) and is the basis of student achievement (Guilloteaux \& Dörnyei, 2008). Past research demonstrates that language learning motivation can potentially improve second language acquisition (Huang, Yang, Chiang, \& Su, 2016; Sung, 2013) as well as willingness-to-communicate (WIC) in English (Liu \& Park, 2012). Similarly, incorporating the use of web resources in EFL classroom activities (Kalanzadeh, Soleimani, \& Bakhtiarvand, 2014) has been found to positively impact the language learner's motivation. Studies conducted on the use of technology in the post-secondary EFL classroom have also revealed that students regard technology in a positive light and

\footnotetext{
${ }^{1}$ This article was produced/improved from the data/text of the author's doctoral thesis.

Citation: Jung, C. D. (2021). Perceptions of collaborative video projects in the language classroom: A qualitative case study. International Journal of Instruction, 14(4), 301-320. https://doi.org/10.29333/iji.2021.14418a
} 
have found its incorporation during classroom activities to be quite motivating (Genc Ilter, 2009; Kalanzadeh et al., 2014).

Having students actively engage in the various steps to create a video collaboratively in pairs or in groups is one method to incorporate technology in the language classroom. Although past research has explored the effects of technology in language learning and teaching, there is currently a lack of conclusive studies that shed light on the relationship between motivation and technology, specifically, pair or small group video projects. A similar past study has shown that the use of student-made video projects at the postsecondary level can benefit student motivation in the classroom (Huang, 2015). Therefore, investigating language learner motivation from a sociocognitive lens focusing on constructs such as self-efficacy (Zhang \& Ardasheva, 2019) and task value (Varasteh, Ghanizadeh, \& Akbari, 2016) allowed for a deeper understanding of the important role of these constructs within the context of technology and motivation.

\section{Sociocognitive Factors of Motivation}

With regard to language learning motivation, self-efficacy is a salient internal factor in the individual. Self-efficacy is defined as how capable one believes that he or she can accomplish a goal (Bong, 2001). Closely linked to task-expectancy, self-efficacy can have an impact on the learner's determination to accomplish a task, the amount of effort to put into the task, and persistence to carry out to completion (Wigfield \& Eccles, 2002). Self-efficacy has also been shown to positively affect cognitive engagement and performance (Bai, Nie, \& Lee, 2020; Karbakhsh \& Safa, 2020; Ugwuanyi, Okeke, \& Asomugha, 2020). A high-perceived self-efficacy is a strong indicator of motivation (Lumbantobing, 2020). Hence, when EFL learners have a firm belief in their ability to achieve a task, they are very likely to be motivated to succeed.

Task value is another factor pertinent with regard to language learning motivation. Task value indicates how much vested interest the language learner has to a particular task or goal (Eccles \& Wigfield, 2002; Wigfield \& Eccles, 2020) and determines if the goal is worthy of pursuit. Thus, task value is determined depending on how strongly the learner believes in the importance of the task. The influence of task value on language learning motivation is an important consideration in the design and implementation of teaching and learning activities in the language classroom.

\section{Collaborative Learning and Motivation}

Within the context of task-based learning in an EFL classroom, collaboration, the peer interaction and learning in a group environment (Doughty \& Long, 2003; KukulskaHulme \& Viberg, 2018; Tavakoli, Lotfi \& Biria, 2019), has been demonstrated to have a beneficial result on language learning motivation. Meaningful peer interaction allows students the opportunity to acquire new knowledge, renegotiate what they know, and develop a better understanding of concepts (Juan-Garau \& Jacob, 2015). Peer group collaboration on projects necessitates the students to take responsibility and ownership of their own learning. Assigned projects that provide authentic learning tasks and handson learning can lead to deeper conceptual understanding and learner autonomy (Vieira, 2017). This type of collaborative teaching approach has been found to contribute to a positive motivational orientation in the students due to greater task-oriented awareness 
(Krajka, 2012). This greater self-awareness elicits self-reflection and improved critical thinking skills in the language learner (Juan-Garau \& Jacob, 2015), traits that are beneficial to learning. In addition to the perception of improved critical thinking skills, collaborative learning has been shown to identify positively with the learner's motivational orientation, cognitive development, and social competence (Warsah, Morganna, Uyun, Hamengkubuwono, \& Afandi, 2021).

\section{Task-Based Language Teaching and Motivation}

Throughout the decades, different pedagogical approaches have been used to motivate students. Since the 1990s with its inception, task-based language teaching (TBLT) has become a popular approach in second language acquisition (SLA) and language learning (Chong \& Reinders, 2020). The real-life relevance and hands-on nature of TBLT attests that language learners learn the language during the process of creating an end-product. TBLT has been demonstrated to engage language learners at various levels. TBLT involves activities that are meaningful tasks utilizing authentic target language (Ellis, 2003). Since its establishment, TBLT which involves scaffolding, mediation, and guided participation, has been widely implemented in the language classroom (Lantolf \& Thorne, 2006). TBLT requires language learners to be actively engaged in all parts of the task to successfully complete it (Hashemi, Azizinezhad, \& Darvishi, 2012). Thereby, the students become active rather than passive learners. TBLT encourages language learners to take initiative and responsibility for their own learning. Learning becomes more meaningful when students are given free rein on the range of topics they can undertake for their project as they are exploring areas of learning that interest them.

More recently, in the last 15 years, more and more researchers have combined TBLT with Computer Assisted Language Learning (CALL) (Chong \& Reinders, 2020) to create a language learning environment that is more meaningful and authentic to the learner. This allows students to become more motivated to learn. Previous research in the field has found that with regards to student motivation, TBLT in conjunction with Computer Assisted Language Learning (CALL) significantly enhanced students' motivation for L2 reading (Tavakoli et al., 2019). Similarly, the use of commercial digital video games was found to help enhance EFL high school students' language learning motivation in Iran (Ebrahimzadeh \& Alavi, 2017).

Other studies have indicated that incorporation of technology such as the use of web resources (Kalanzadeh et al., 2014) in the foreign language classroom can contribute to language learning motivation as well. University students view technology use in language classrooms positively (Genc Ilter, 2009; Kalanzadeh et al., 2014) and therefore, greater motivation to use technology to learn English. The comfort and familiarity of using technology in their personal lives makes it easy to extend its use to the classroom for language learning purposes. Numerous studies have been conducted on language learning through technology use (de la Guia, Camacho, Orozco-Barbosa, Brea Lujan, Penichet, \& Lozano Perez, 2016; Rashid, Cunningham, \& Watson, 2017). Of significant importance is that the integration of technology with TBLT results in many positive effects in the language learner such as improvements in motivation and 
cognitive processes during task performance (Lai \& $\mathrm{Li}, 2011$ ) as well as listening comprehension (Mulyadi, Wijayatiningsih, Singh, \& Prastikawati, 2021).

\section{The South Korean Context}

Since 1997, many changes in the national curriculum have led to its seventh version in South Korea (Hereafter, "Korea"). Changes were mandated by the Ministry of Education for all school subjects including English education. However, the current English education curriculum leaves much to be desired with regards to its efficacy as there appears to be a strong disconnect between the national English curriculum and its classroom implementation. The emphasis on standardized testing at the secondary level, colloquially referred to as "teaching to the test" (Byean, 2015), has been shown to be detrimental to students' motivation to learn English. In reference to the type of motivation Korean students possess, a recent study conducted at a university in Seoul found that students were predominantly motivated by extrinsic reasons to study English (Geddes, 2016). Various motivational strategies have been utilized to motivate and encourage students in the post-secondary classroom in Korea. Korean university students reported that of particular importance is the EFL professor's ability to conduct various classroom activities in a pleasant atmosphere conducive to learning (Heinz \& Kobylinski, 2017). In another related study on 255 randomly-selected Korean EFL students, a strong correlation was found between self-esteem and motivation (Basco \& Han, 2016).

Previous studies demonstrate the advantageous role of implementing technology in a post-secondary EFL classroom and provide strong support for the incorporation of video projects to study the impact on students' EFL motivation. What is new about this present study is that video projects are explored in a post-secondary Korean context and the findings are analyzed through the sociocognitive indicators of motivation, self-efficacy and task expectancy. Thus, this study adds to the lack of literature on student-made video projects within the EFL motivational context of post-secondary Korean students.

\section{Purpose of This Study}

The purpose of this case study is to explore how post-secondary EFL students perceive the impact of video projects on their motivation for learning English in Korea through a sociocognitive lens. Furthermore, this research captures how students describe their experiences with student-made video projects taught within the pedagogical approach of TBLT. Numerous past studies have documented positive outcomes on motivation through student-led video projects in contexts outside of EFL (Larmer, 2014; McCaslin \& Young, 2015; Mistry, Bignante, \& Berardi, 2016; Ranker, 2008). However, with the exception of a few studies (Abdulrahman \& Basalama, 2019; Huang, 2015), there is currently very little research in the field on the effects of student-led video projects in the post secondary EFL classroom. As such, this study attempted to relieve the scarcity of research specifically relating to the post-secondary EFL context and aid in the advancement of current understandings of EFL motivation at the post-secondary level in Korea. This study answers the following research questions: 
1) How do students experience the process of creating videos to learn and practice English?

2) How do students view the impact of task-based language teaching through the creation of video projects on their motivation for learning English?

\section{METHOD}

\section{Research Setting}

The research setting for this qualitative case study was an EFL classroom within a private university in Daejeon, South Korea. Participants came from two different classes each taught by two different EFL instructors. Students were taught how to create the videos through the TBLT pedagogical approach by their instructors. Thus, the instructors acted more as facilitators as the classes were student-centered. Students were taught about the concept of infomercials during class time and provided with various materials to create an original script. The students worked together in pairs both during and outside of class. The purpose of the video project was to create an original infomercial video in pairs about an imaginary product they would find very useful in their lives. Within the context of the TBLT approach, the focus was on the videomaking process.

\section{Population and Sample}

Before the start of the video project, the participants appeared to exhibit a strong sense of motivation. In the pre-project stage, a positive motivational orientation was displayed when participants reported that they were highly motivated to learn English due to extrinsic factors. Such reasons included the desire to please parents, communicate with extended family residing overseas, supportive teachers and peers, technology, getting a good grade in the class and a high TOEIC score, and necessity of English for employment.

In this study, purposeful sampling was used in which the researcher selected specific participants and locations to understand a particular phenomenon (Creswell, 2015). Due to the exploratory nature of this research, an in-depth focus on the rich, lived-in experiences of the participants was necessary. As such, a sample size of eight participants was deemed appropriate. The selection criteria for participation were twofold: the participant had willingly given consent to be included in the study and was also a freshman student enrolled in a task-based EFL course. Participants in this study ranged between 18 to 20 years of age and had a total of nine years of English learning experience. The data was based on four male participants and four female participants. Two of the participants were engineering majors. The remaining participants were hospital management majors. Scores on an English proficiency test administered schoolwide before the beginning of the semester determined that the participants' English proficiency levels were at the intermediate level.

Data on participant demographics including the participants' pseudonyms, age, gender, university major, and total number of years of English-learning experience are provided in the table (Table 1) below. 
Table 1

Participant demographics

\begin{tabular}{lllll}
\hline $\begin{array}{l}\text { Participant } \\
\text { Pseudonym }\end{array}$ & Age & Gender & Major & $\begin{array}{l}\text { Total number of years of } \\
\text { English learning experience }\end{array}$ \\
\hline Ulysses & 18 & M & healthcare management & 9 \\
\hline Sam & 18 & M & healthcare management & 9 \\
\hline Yuna & 18 & F & healthcare management & 9 \\
\hline Hannah & 18 & F & healthcare management & 9 \\
\hline Eunice & 18 & F & healthcare management & 9 \\
\hline Nina & 18 & F & healthcare management & 10 \\
\hline Jae & 20 & M & railroad vehicle system engineering & 16 \\
\hline Mike & 18 & M & railroad vehicle system engineering & 9 \\
\hline Not
\end{tabular}

Note. $\mathrm{M}=$ male; $\mathrm{F}$ = female.

\section{Data Collection}

Over a period of 12 weeks, data collection occurred with the participants. Data was collected through field notes, a reflection journal, semi-structured interviews, studentmade video projects, and student reflection papers. As the researcher is bilingual in English and Korean, the participants were given the option of conducting the interviews in either language or both. Each interview lasted about 50 minutes to one hour in length. Audio recordings of these semi-structured interviews with participants, researcher field notes during the interviews, summary notes for each interview, student-made infomercial videos, and participants' reflection papers ensured data triangulation. Verification for accuracy of the audio transcripts for the interviews and summaries was done through member checks. This study was divided into two stages: the pre-project and post-project stage.

During the pre-project stage, the first set of semi-structured interviews were conducted. These pre-project interviews elicited data in response to the research questions pertaining to the participants' motivational orientations to learn English. It also included questions about their previous English learning experiences.

In the post-project stage, the second and final set of semi-structured interviews were administered after the completion of the infomercial video project. In this interview, questions were asked about the students' perceptions about their video projects and how they felt about the entire process with regards to their EFL-learning motivation. The video projects were played at the beginning of the interview as a starting point.

Detailed field notes during the semi-structured interviews and researcher reflections were maintained in a reflection journal. The information recorded in the researcher's reflections contained factual data about the interview and participant reflections. The researcher's reflections component consisted of a detailed analysis of each interview.

\section{Data Analysis}

Two sets of in-depth semi-structured interviews were conducted to collect the information-rich lived-in experiences of the participants. All responses were taken note of in the researcher journal as well as audio-recorded. During the first interview session (pre-project interview), general open-ended questions were asked and answered which 
pertained to their motivational orientations including questions pertaining to past motivational influences. In the second interview (post-project interview), questions relating to their work on their video projects were asked which were based on the specific motivational constructs self-efficacy and task expectancy, strong indicators of motivation. Every interview was transcribed manually by the researcher. Participants then summarized their video project experience through a reflection paper after project completion. Finally, all of the participants' infomercial video projects were viewed by the researcher a second time and analyzed. Notes of the video analysis were documented in the researcher reflection journal. Data was thematically analyzed through open and axial coding.

\section{FINDINGS}

Based on analysis of the data, the participants' video-making experiences were generally positive and motivational orientation remained high, although there were times when it fluctuated due to frustrations caused by technical difficulties stemming from computer and editing software incompatibility, lack of props and venues during filming, and a tight schedule due to other course deadlines. However, overall, participants reported positive perceptions in relation to the perceived impact of video projects on their motivational orientation. This was evident in the responses of the participants about their experiences with the video project. The responses analysed by open and axial coding led to the formation of categories. These categories led to codes that were grouped and regrouped. Examples of original categories include most interesting parts of making the video, reasons for experiencing difficulty during the video-making process, new learnings from working on the project, motivational orientation during video project creation, and perceived motivational changes and opinions about learning English after completing video project. Table 2 shows examples of codes. 
Table 2

Examples of some categories and codes

\begin{tabular}{|c|c|}
\hline Category & Codes \\
\hline Most interesting parts of making the video & $\begin{array}{l}\text { Filming in locations } \\
\text { Working with partners and peers } \\
\text { Getting to know peers better } \\
\text { Creating script } \\
\text { Singing and dancing } \\
\text { Acting out the script } \\
\text { Making bloopers } \\
\text { Learning new English words and expressions }\end{array}$ \\
\hline $\begin{array}{l}\text { Reasons for experiencing difficulty during } \\
\text { the video-making process }\end{array}$ & $\begin{array}{l}\text { Miscommunication with instructor } \\
\text { Misunderstanding of the instructor } \\
\text { Differences of opinions with partner } \\
\text { Memorizing script } \\
\text { Using gestures while filming } \\
\text { Acting on camera } \\
\text { Film editing } \\
\text { Film editing software issues } \\
\text { Tight deadline } \\
\text { Lack of props } \\
\text { Finding good filming location }\end{array}$ \\
\hline New learnings from working on the project & $\begin{array}{l}\text { New English vocabulary and expressions } \\
\text { Diplomacy skills } \\
\text { Desire to improve English skills } \\
\text { Leadership } \\
\text { Responsibility } \\
\text { Computer/technical skills } \\
\text { Cooperation skills } \\
\text { Improvement in sentence writing skills } \\
\text { Improvement in speaking skills } \\
\text { Improvement in pronunciation } \\
\text { Self-directed learning } \\
\text { Time management }\end{array}$ \\
\hline $\begin{array}{l}\text { Motivational orientation during video } \\
\text { project }\end{array}$ & $\begin{array}{l}\text { Fluctuations } \\
\text { Went down } \\
\text { No change } \\
\text { Perceived increase in motivation }\end{array}$ \\
\hline $\begin{array}{l}\text { Perceived motivational changes and } \\
\text { opinions about learning English after } \\
\text { completing video project }\end{array}$ & $\begin{array}{l}\text { No change in motivation } \\
\text { Perceived increase in motivation } \\
\text { Learning English is more enjoyable } \\
\text { Increased confidence } \\
\text { English is not as hard as before } \\
\text { Positive memories }\end{array}$ \\
\hline
\end{tabular}

The thematic analysis of the data resulted in four major themes: self-efficacy, task value, peer collaboration, and important skills.

\section{Self-Efficacy}

During both the pre-project and post-project stages, participants stated that they felt a strong need to further improve their English proficiency in the future. Eunice asserted: 
For me, as time goes by, it is becoming more fun. Maybe because of the project but class is becoming more fun as time goes by. In the beginning when the professor asked questions, I felt a little apprehensive to answer questions. Maybe because I kept on speaking, during class and in the video project, I feel I can hear and understand better. So, as I speak more, I participate better and have more interest. I like class better. I've gotten better...

As can be seen by her statement above, Eunice attributed her enjoyment of class most likely to the video project. In addition, she appeared to exhibit both a high self-efficacy and self-confidence when it comes to learning English. She stated:

I have a lot of confidence. I really like discussions with many people. I have no fear or qualms about asking questions to the professor. Because our past English classes were based on CSAT prep and listening focused, it is hard to speak out in English. How do we say this in English and I feel blocked. But [now] because we talk in English with the professor for one semester, I think that I will learn to speak really well in English (chuckles).

However, it was interesting to discover that self-confidence did not always equate with a high self-efficacy for the participants in this study. For participant Nina, this was the case. She explained:

When I was young, I thought that saying one English word was enough for communication. But as I got older, I realized that I need to speak in sentences. Up until now I only really learned English implicitly rather than conversationally so I feel that I really lack in my English ability. So, because of this, I still feel a little fear.

Given her statement above, however, Nina emphasized that her perceived lack of selfconfidence when speaking in English did not negatively impact her motivation to learn English at all.

\section{Task Value}

Results seem to indicate that the participants' motivation level was positively impacted due to a high task value for the video project. We can see evidence of a high task value of the video project through the demonstrated amount of dedication and engagement of the participants while working on the project together. For example, when asked how many retakes they did due to mistakes they made while filming, Nina said, "About 50. And I made 20 of the NGs during the introduction." For participant Ulysses, he appeared to put a high task value on the project as he stated that it allowed him to become closer to his partner and classmates which is very important for him. He stated that the most meaningful part about the infomercial video project for him was the opportunity to help one another while filming and consequently, become better friends with his peers. Thus, completing this project helped him develop deeper friendships with his peers which encouraged him to more actively engage in the project as he became more invested in it. We can also see evidence of a high task value through participant Mike's self-reflection about the project. About his infomercial video, Mike stated: 
This project we make our product. It's very interesting for me. Not other product. Our product we sells. So, we deliver our product much better than other products. So, I can sell very well because I love my product Language Food. So, it's very interesting for me.

Mike and his partner Jae also prepared several food props by going shopping for them together. Mike displayed a perfectionist personality regarding the video as video-making is one of his hobbies. Of this, Mike stated, "Jae said, 'Hey don't use sushi. Ramen is Japanese too!' I said, 'No! Always sushi! Not ramen!'” Thus, a high task value for the video project is represented by his ardent enthusiasm for his infomercial topic, Language Food, pushing him to create a video that went much more beyond the minimum requirements. Similarly, when asked why they included subtitles in their video when it was not a requirement, participant Yuna remarked, "That was because we wanted the person who is watching to watch more comfortably...Because our pronunciation is not that good, we didn't think that the viewer would be able to understand what we said." Therefore, both Mike and Yuna's group went the extra mile for the video project because of their desire to do the best they could. Thus, for these reasons, it is conclusive that the high task value the participants possessed during the process of creating the infomercial video contributed positively to their language learning motivation.

\section{Peer Collaboration}

It appeared that peer collaboration had a positive effect on motivation as well. Of his partner, Sam stated, "Thanks to Ulysses, we were able to conduct this project very vigorously and so it was very good." Likewise, participant Yuna revealed that her peer collaboration experience with her partner had a positive effect on her engagement and motivation for the project. Of her collaborative experience, Yuna stated, "My partner Hannah and my opinion is correct and the preparation for the task was fun. Honestly, there were many ideas but from among those, we chose one. We wanted to make it fun so it was fun." When asked what she discovered her strength was while working on the video project with her partner, Eunice elucidated:

For me, it was working together. When I see each person having tasks assigned, either making the script, editing, this is how it was usually divided. Nina and are both ambitious. But we were afraid that we would have differences in opinions and thinking which would cause issues so we decided to do everything together from the start.

Similarly, participant Nina learned that good communication and cooperation with peers is key to a successful project outcome. In her words, she explained:

Um, even if our opinions differ, we learned that it is important to try to concede or yield. Also, I learned that making this video with others rather than just on my own is more meaningful. I think it's better.

Nina sums up the final thoughts of many of her peers after successful completion of the infomercial video project: "In the final wrap-up session right before we submitted the 
video, we watched our finished video. We felt warm and fuzzy. Whether it was good or not, we did it." Hence, peer collaboration during the video-making process enabled the participants to assist and encourage one another through a supportive and collegial atmosphere, positively affecting their motivational orientation.

\section{Important Skills}

Through the creation of the infomercial video project, participants acquired improvements in some technological and English proficiency skills. Learning how to video edit and add special effects were skills that participant Yuna gained. "Within editing, I learned how to put in subtitles and special effects for the first time." For Nina, her partner Eunice was very helpful with the video. She revealed, "Eunice made the video in the past but for me it was the first time. Together, we put in this and that. I think my computer savvy increased." Even Mike, a film connoisseur, learned many new techniques with the editing software that he used. He commented, "Actually, movie or drama it doesn't use text or image. So, through this project, I can use text and images technique. So, it's very good." This project allowed Mike the opportunity to experiment at a higher level with the various functions he never tried before using video editing software such as creating subtitles and special effects. In addition, many participants reported improvements in their English proficiency skills, specifically speaking, writing, and listening. When asked which English skill she thought improved the most, Nina elaborated on her improved speaking skill:

Even in the past in middle and high school, for speaking, the performance evaluation always occurred at least once. Every time I had the evaluation, I got nervous and had trouble speaking. From this [video project], I got a lot of practice speaking so this time, I presented about social media... I think I spoke better.

Similarly, participants were able to add to their English vocabulary knowledge while developing the script for their videos. For example, for their Young Zoo Cure infomercial on an analgesic, Yuna and her partner expanded their knowledge of English vocabulary on human ailments such as the word "cramps" and the expression, "Do you ever get menstrual cramps?" Likewise, from Nina and her partner's video Chiropractic Slippers: "This helps your body circulate blood and remove swelling from your legs," is also not a typical expression a student would learn from an EFL class or textbook. However, they are helpful in practical life situations and can be used in various settings which is one of the purposes of communicative language teaching. For Mike, "Let's go live," is another new English expression that he learned when making his script for his infomercial video. He asserted, "Textbook don't teach me 'twenty-nine, ninety-nine' (\$29.99) and 'One-tenths of the price." Thus, it is obvious that participants acquired various useful skills while completing their video projects. 


\section{DISCUSSION}

\section{How Students Experienced the Process of Creating Videos to Learn and Practice English}

The participants' project engagement, learning experiences, and perceptions with regard to the video projects are in line with the current research conducted on language learners' experiences with technology which are generally viewed as effective for language learning motivation (Ahmadi \& Reza, 2018; Alsied \& Pathan, 2013; Chen, 2020; Kalanzadeh et al., 2014; Tsai, 2020; Wu, Yen, \& Marek, 2011). Based on the findings, there appeared to be a strong emotional conviction and motivation to succeed in the participants. The learner's emotional conviction is an embodiment of the desire to achieve more through various extrinsic and intrinsic factors (de Burgh-Hirabe \& Feryok, 2013). Support for this is found in the pre-project stage where many participants stated that they were motivated to study English due to extrinsic reasons stemming from family, classroom teacher, peers, technology, and future career. The results further support the findings of Daif-Allah \& Aljumah (2020) who found that in a study of 247 Saudi male and female EFL students, highly ranked on the list of motivation to learn EFL were for better future employment opportunities and the desire to communicate knowledge and culture as well as form friendships with English-speaking foreigners. Similarly, the conclusions of other previous studies further support the results of this study that indicate the important influence of the teacher on language learners' motivation $(\mathrm{Ng} \& \mathrm{Ng}, 2015)$ and the positive impact of using technology to increase intrinsic motivation and engagement (Sun \& Hseih, 2018).

During the project implementation stage, it appeared that motivational orientation was positively impacted in many of the students due to the influence of peer collaboration, a finding which supports past research on the positive influence of collaborative dialogue (Swain, 2000) within the context of task-based language activities. Challenges are often alleviated by fellow peers when working together in groups. This alleviation brought on by the support of colleagues can lead to a positive impact on motivation, classroom engagement, and camaraderie (Kiefer, Alley, \& Ellerbrock, 2015). In the case of the participants in this study, collegial support occurred during technical difficulties, script memorization and acting struggles when motivational orientation may have become negatively impacted.

Finally, the post-project stage consisted of the participants sharing their video-making learning experience. The final reflections of the participants and their finished products revealed that the interactive and peer collaborative nature of the video project was an enjoyable and memorable experience for them. Because of this video project, participants also reported improvements in their motivation level and English proficiency skills such as speaking, listening, and writing abilities. They also noted perceived improvements in their vocabulary knowledge. These reported experiences corroborated with those of the participants in Huang's (2015) study where the participants stated that they experienced improvements in their overall English proficiency as evidenced through improved TOEIC test scores and indicated that their 
interest and motivation were maintained because of the fun nature of creating the video. Likewise, the possession of self-efficacy in the participants resulting in a positive effect on engagement and performance in the task also mirrors the findings of Bai et al., (2020); Karbakhsh \& Safa, (2020); \& Ugwuanyi et al., (2020) as noted in the literature review. Similar to Lumbantobing's (2020) study, a high-perceived self-efficacy was a strong indicator of high motivation in the participants of this video project study. Similarly, a recent study on the effects of project-based learning on student teacher selfefficacy and achievement reveals a significant difference between the experimental and control group (Mahasneh \& Alwan, 2018) lending further support for the effectiveness of project or task-based learning on improving self-efficacy and achievement in language learners. Task value (Eccles \& Wigfield, 2002; Wigfield \& Eccles, 2020), the other sociocognitive indicator of motivation applicable to this study, was evidently high in the participants due to their strong, predominantly extrinsic, motivation. Like participant Mike who happened to be mainly intrinsically motivated by the video project, the rest of the predominantly extrinsically motivated participants also placed a high task value on the video project due to a strong desire to succeed in the EFL course. This study's findings are also consistent with Shin's (2018) study among 79 Korean EFL university students in Korea which indicated that the collaborative creation of video projects of scripted job interview scenario role plays resulted in increased motivation and self-efficacy among students as well as enhance cooperation skills.

\section{Participants' Views of the Impact of TBLT through the Creation of Video Projects}

The participants' positive views of the impact of TBLT align strongly with their favorable opinion for the use of technology, aiding in language learning motivation. Improvements in English proficiency skills and vocabulary acquisition in addition to technological skills like video editing that the participants experienced through TBLT and technology are supported by current literature in the field (Abdulrahman \& Basalama, 2019; de la Guia, Camacho, Orozco-Barbosa, Brea Lujan, Penichet, \& Lozano Perez, 2016; Genc Ilter, 2009; Huang, 2015; Kalanzadeh et al., 2014; Mulyadi, Wijayatiningsih, Singh, \& Prastikawati, 2021; Rashid, Cunningham, \& Watson, 2017). Their positive reflections are expressed through their conveyed feelings and opinions about the video project. It is of importance to note that this study also brings to light the efficacy of combining TBLT and technology in the students' acquisition of English vocabulary used in specific fields or English for Specific Purposes (ESP). This type of communicative English instruction is learner-centered and discipline-based (Hyland, 2007) which is useful for the student's particular major. The participants developed knowledge of English vocabulary unique to their particular projects and majors. Their learning experiences and perceptions of the project are evidence of the synergistic effect of TBLT and technology on language learning (Doughty \& Long, 2003; GonzálezLloret \& Ortega, 2014).

The integration of TBLT and technology could lessen the language learning apprehension of students (González-Lloret \& Ortega, 2014). Reducing the students' learning fears, or lowering students' affective filters, results in a greater amount of language output in the course of task completion (Lai \& Li, 2011). Language output 
increase can induce a positive chain reaction in which the resulting greater speaking fluency produces increased confidence and self-efficacy in the student. This then leads to an increase in EFL learning motivation, supplying the drive for the learner to complete a task. During the course of creating the video project, participants showed evidence of demonstrating this positive chain reaction with regards to their motivation. Figure 1 below illustrates the effect that TBLT and technology have on the participants with regard to their motivation.

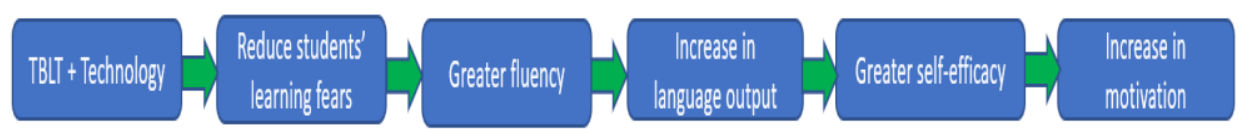

Figure 1

A flowchart of the effect of TBLT and technology on the language learner

Thus, the reported feelings and opinions of the participants in this study strongly correlate with the theoretical underpinnings of González-Lloret \& Ortega (2014) as the combined effects of TLBT and technology in the form of the infomercial video project proved to be a unique and interesting experience for many of them. For the participants, this project was a chance to create something distinctive with their peers in an environment that is safe and supportive. When students feel comfortable and secure in their learning environment, learning becomes more effective. It also helps bring fellow peers closer together as they learn and encourage one another.

Task-based language activities incorporated with technology augments the social cohesiveness of EFL learners (Biria \& Jafari, 2013; Kukulska-Hulme \& Viberg, 2018; Lai \& Li, 2011). For instance, mobile technologies, including smartphones and tablets, which have become quite ubiquitous, have proven to support collaborative learning among EFL learners as well as improve their levels of motivation, engagement, and selfconfidence (Kukulska-Hulme \& Viberg, 2018). Through collaborative task-based language activities infused with various forms of technology, social cohesiveness can have a positive influence on the EFL learner's language learning, and therefore, motivation. Hence, based on similar past studies as discussed above, this present study provides additional support and new insight into the effectiveness of utilizing technology, specifically student-made video projects, to positively impact EFL students' language learning motivation through authentic and meaningful peer collaborative learning opportunities.

\section{CONCLUSION}

Findings from this study conclude that the participants, in general, reported positive perceptions of their motivation to learn English in relation to their engagement with video projects based on their collaborative and technology-enhanced learning experience. Additionally, findings also point to the role of sociocognitive constructs of motivation, specifically self-efficacy and task value, in the perceived influence of video projects on language learner motivation. This study also contributes to addressing the existing research gap on Korean post-secondary EFL students regarding the synergistic 
effect of TBLT and technology on language learner motivation. Stemming from the findings of this research, incorporating student-made video projects through TBLT in post-secondary EFL curricula is strongly recommended. It would be better for educators to focus on authentic learning activities that allow language learners to take greater ownership of their learning, regardless of their language proficiency level and age. Projects that combine TBLT and technology on specific topics that are tailored to be interesting and meaningful to students would positively impact language learner motivation.

This study provides EFL educators evidence to create curricula and course offerings that incorporate the use of video projects in post-secondary classrooms. In addition, they ought to consider the students' particular interests and have them work together collaboratively in pairs or groups to benefit from peer learning and a support system. Thus, a significant factor to consider when it comes to EFL motivation in universities is the use of technology, specifically video projects. Future research would consider making classroom observations and examining students' translanguaging practices during creation of video projects and how they support their learnings and motivation with regard to language learning.

\section{ACKNOWLEDGEMENT}

This research study was supported by Woosong University Research Funding 2020.

\section{REFERENCES}

Abdulrahman, T. R., \& Basalama, N. (2019). Promoting students' motivation in learning English vocabulary through a collaborative video project. Celt, 19(1), 107-137. doi: 10.24167/celt.v19i1.493

Ahmadi, D., \& Reza, M. (2018). The use of technology in English language learning: A literature review. International Journal of Research in English Education, 3(2), 115 125 .

Alsied, S. M., \& Pathan, M. M. (2013). The use of computer technology in EFL classroom: Advantages and implications. International Journal of English Language \& Translation Studies, 1(1), 61-71.

Bai, B., Nie, Y., \& Lee, A. N. (2020). Academic self-efficacy, task importance and interest: relations with English language learning in an Asian context. Journal of Multilingual and Multicultural Development, 1-14.

Basco, L. M., \& Han, S-H. (2016). Self-esteem, motivation, and anxiety of Korean university students. Journal of Language Teaching and Research, 7(6), 1069-1078. doi: 10.17507/jltr.0706.02

Biria, R., \& Jafari, S. (2013). The impact of collaborative writing on the writing fluency of Iranian EFL learners. Journal of Language Teaching and Research, 4(1), 164-175. doi: $10.4304 /$ jltr.4.1.164-175 
Bong, M. (2001). Between-and within-domain relations of academic motivation among middle and high school students: Self-efficacy, task-value, and achievement goals. Journal of Educational Psychology, 93(1), 23-34. doi: 10.1037/0022-0663.93.1.23

Byean, H. (2015). English, tracking, and neoliberalization of education in South Korea. TESOL Quarterly, 49(4), 867-882. doi: 10.1002/tesq.257

Chen, C. H. (2020). AR videos as scaffolding to foster students' learning achievements and motivation in EFL learning. British Journal of Educational Technology, 51(3), 657672.

Cheng, H., \& Dörnyei, Z. (2007). The use of motivational strategies in language instruction: The case of EFL teaching in Taiwan. Innovation in Language Learning and Teaching, 1(1), 153-174. doi: 10.2167/illt048.0

Chong S.W., \& Reinders H. (2020). Technology-mediated task-based language teaching: A qualitative research synthesis. Language Learning \& Technology, 24(3), $70-86$.

Creswell, J. (2015). Educational research: Planning, conducting, and evaluating quantitative and qualitative research (4th ed.). Upper Saddle River, NJ: Pearson Education Inc.

Daif-Allah, A. S., \& Aljumah, F. H. (2020). Differences in motivation to learning English among Saudi university students. English Language Teaching, 13(2), 63-74.

de Burgh-Hirabe, R., \& Feryok, A. (2013). A model of motivation for extensive reading in Japanese as a foreign language. Reading in a Foreign Language, 25(1), 72-93. Retrieved from http://www.nflrc.hawaii.edu/rfl/April2013/articles/deburgh.pdf

de la Guia, E., Camacho, V., Orozco-Barbosa, L., Brea Lujan, V., Penichet, V., \& Lozano Perez, M. (2016). Introducing IoT and wearable technologies into task-based language learning for young children. IEEE Transactions on Learning Technologies, 9(4), 366-378. doi: 10.1109/TLT.2016.2557333

Doughty, C. J., \& Long, M. H. (2003). Optimal psycholinguistic environments for distance foreign language learning. Language, Learning \& Technology, 7(3), 50-80. doi: $10125 / 25214$

Ebrahimzadeh, M., \& Alavi, S. (2017). The effect of digital video games on EFL students' language learning motivation. Teaching English with Technology, 17(2), 87112 .

Eccles, J., \& Wigfield, A. (2002). Motivational beliefs, values, and goals. Annual Review of Psychology, 53, 109-132. doi: 10.1146/annurev.psych.53.100901.135153

Ellis, R. (2003). Task-based language learning and teaching. New York: Oxford University Press. 
Geddes, A. J. (2016). Korean university students' attitudes and motivation towards studying English. Universal Journal of Educational Research, 4(4), 704-715. doi: 10.13189/ujer.2016.040407

Genc Ilter, B. (2009). Effect of technology on motivation in EFL classrooms. Turkish Online Journal of Distance Education, 10(4), 136-158. doi: 10.17718/TOJDE.37730

González-Lloret, M., \& Ortega, L. (2014). Towards technology-mediated TBLT: An introduction. In M. González-Lloret \& L. Ortega (Eds.), Technology-mediated TBLT: Researching technology and tasks (pp. 1-22). Amsterdam: John Benjamins Publishing Company.

Guilloteaux, M., \& Dörnyei, Z. (2008). Motivating language learners: A classroomoriented investigation of the effects of motivational strategies on student motivation. TESOL Quarterly, 42(1), 55-77. doi: 10.1002/j.1545-7249.2008.tb00207.x

Hashemi, M., Azizinezhad, M., \& Darvishi, S. (2012). Using task-based language teaching, learning practically in English classes. Procedia - Social and Behavioral Sciences, 31(2011), 526-529. doi: 10.1016/j.sbspro.2011.12.098

Heinz, M., \& Kobylinski, C. (2017). Korean university students' perceptions of teacher motivational strategies. International Journal of Learning, Teaching, and Educational Research, 16(9), 29-41. doi: 10.26803/ijlter.16.9.3

Huang, C., Yang, S., Chiang, T., \& Su, A. (2016). Effects of situated mobile learning approach on learning motivation and performance of EFL students. Journal of Educational Technology \& Society, 19(1), 263-276.

Huang, H. (2015). The effects of video projects on EFL learners' language learning and motivation. International Journal of Computer-Assisted Language Learning and Teaching, 5(1), 53-70. doi: 10.4018/IJCALLT.2015010104

Hyland, K. (2007). English for specific purposes. In J. Cummins \& C. Davison (Eds.), International handbook of English language teaching (Vol. 15, pp. 391-402). Boston MA: Springer.

Juan-Garau, M., \& Jacob, K. (2015). Developing English learners' transcultural skills through content- and task-based lessons. System, 54, 55-68. doi: 10.1016/j.system.2015.04.017

Kalanzadeh, G., Soleimani, H., \& Bakhtiarvand, M. (2014). Exploring the influence of using technology on Iranian EFL students' motivation. Procedia - Social and Behavioral Sciences, 98, 814-823. doi: 10.1016/j.sbspro.2014.03.486

Karbakhsh, R., \& Safa, M. (2020). Basic psychological needs satisfaction, goal orientation, willingness to communicate, self-efficacy, and learning strategy use as predictors of second language achievement: A structural equation modeling approach. Journal of Psycholinguistic Research, 49(5), 803-822. 
Kiefer, S., Alley, K., \& Ellerbrock, C. (2015). Teacher and peer support for young adolescents' motivation, engagement, and school belonging. RMLE Online, 38(8), 1-18. doi: 10.1080/19404476.2015.11641184

Krajka, J. (2012). Web 2.0 online collaboration tools as environments for task-based writing instruction. Ankara Üniversitesi Eğitim Bilimleri Fakültesi Dergisi, 45(2), 97118.

Kukulska-Hulme, A., \& Viberg, O. (2018). Mobile collaborative language learning: State of the art. British Journal of Educational Technology, 49(2), 207-218. doi: $10.1111 /$ bjet. 12580

Lai, C., \& Li, G. (2011). Technology and task-based language teaching: A critical review. CALICO Journal, 28(2), 1-24. doi: 10.11139/cj.28.2.498-521

Lantolf, J., \& Thorne, S. (2006). Sociocultural theory and the genesis of second language development. Oxford: Oxford University Press.

Larmer, J. (2014). Boosting the power of projects. Educational Leadership, 72(1), 4246.

Liu, Y., \& Park, H. (2012). A study of Korean EFL learners' WTC and motivation. Pan-Pacific Association of Applied Linguistics, 16(2), 35-58.

Lumbantobing, P. A. (2020). The contribution of lecturer pedagogical competence, intellectual intelligence and self-efficacy of student learning motivation. Budapest International Research and Critics in Linguistics and Education (BirLE) Journal, 3(1), 564-573.

Mahasneh, A. M., \& Alwan, A. F. (2018). The effect of project-based learning on student teacher self-efficacy and achievement. International Journal of Instruction, 11(3), 511-524. doi: 10.12973/iji.2018.11335a

McCaslin, S., \& Young, M. (2015). Increasing student motivation and knowledge in mechanical engineering by using action cameras and video productions. Advances in Production Engineering \& Management, 10(2), 87-96. doi: 10.14743/apem2015.2.194

Mistry, J., Bignante, E., \& Berardi, A. (2016). Why are we doing it? Exploring participant motivations within a participatory video project. Area, 48(4), 412-418. doi: 10.1111/area.12105

Mulyadi, D., Wijayatiningsih, T. D., Singh, C. K. S., \& Prastikawati, E. F. (2021). Effects of technology enhanced task-based language teaching on learners' listening comprehension and speaking performance. International Journal of Instruction, 14(3), 717-736.

Ng, C. F., \& Ng. P. K. (2015). A review of intrinsic and extrinsic motivations of ESL learners. International Journal of Languages, Literature and Linguistics, 1(2), 98-105. 
Ranker, J. (2008). Making meaning on the screen: Digital video production about the Dominican Republic. Journal of Adolescent \& Adult Literacy, 51(5), 410-422. doi: 10.1598/JAAL.51.5.4

Rashid, S., Cunningham, U., \& Watson, K. (2017). Task-based language teaching with smartphones. Teachers and Curriculum, 17(2), 33-40. doi: 10.15663/tandc.v17i2.173

Shin, M. H. (2018). Effects of project-based learning on students' motivation and selfefficacy. English Teaching, 73(1), 95-114.

Sun, J. C.-Y., \& Hsieh, P.-H. (2018). Application of a gamified interactive response system to enhance the intrinsic and extrinsic motivation, student engagement, and attention of English learners. Educational Technology \& Society, 21 (3), 104-116.

Sung, K. (2013). L2 motivation in foreign language learning. Journal of Language and Linguistic Studies, 9(2), 19-30.

Swain, M. (2000). The output hypothesis and beyond: Mediating acquisition through collaborative dialogue. In J. P. Lantolf (Ed.), Sociocultural theory and second language learning (pp. 97-114). Oxford: Oxford University Press.

Tavakoli, H., Lotfi, A., \& Biria, R. (2019). Effects of CALL-mediated TBLT on motivation for L2 reading. Cogent Education, 6(1), 1-21.

Tsai, C-C. (2020). The effects of augmented reality to motivation and performance in EFL vocabulary learning. International Journal of Instruction, 13(4), 987-1000. doi: 10.29333/iji.2020.13460a

Ugwuanyi, C. S., Okeke, C. I., \& Asomugha, C. G. (2020). Prediction of Learners' Mathematics Performance by Their Emotional Intelligence, Self-Esteem and SelfEfficacy. Cypriot Journal of Educational Sciences, 15(3), 492-501.

Varasteh, H., Ghanizadeh, A., \& Akbari, O. (2016). The role of task value, effortregulation, and ambiguity tolerance in predicting EFL learners' test anxiety, learning strategies, and language achievement. Psychological Studies, 61(1), 2-12.

Vieira, F. (2017). Task-based instruction for autonomy: Connections with contexts of practice, conceptions of teaching, and professional development strategies. TESOL Quarterly, 51(3), 693-715. doi: 10.1002/tesq.384

Warsah, I., Morganna, R., Uyun, M., Hamengkubuwono., \& Afandi, M. (2021). The impact of collaborative learning on learners' critical thinking skills. International Journal of Instruction, 14(2), 443-460. doi: 10.29333/iji.2021.14225a

Wigfield, A., \& Eccles, J. (2002). The development of competence beliefs, expectancies for success, and achievement values from childhood through adolescence. In A. Wigfield, \& J. Eccles (Eds.), The development of achievement motivation (pp. 91-120). San Diego, CA: Academic Press. 
Wigfield, A., \& Eccles, J. (2020). 35 years of research on students' subjective task values and motivation: A look back and a look forward. In Advances in motivation science (Vol. 7, pp. 161-198). Elsevier.

Wu, W. C. V., Yen, L. L., \& Marek, M. (2011). Using online EFL interaction to increase confidence, motivation, and ability. Journal of Educational Technology \& Society, 14(3), 118-129.

Zhang, X., \& Ardasheva, Y. (2019). Sources of college EFL learners's self-efficacy in the English public speaking domain. English for Specific Purposes, 53, 47-59. 